\title{
Contractarian Libertarianism of Jan Narveson. Is It Still Libertarianism?
}

\section{El libertarismo contractualista de Jan Narveson. ¿Realmente un libertarismo?}

\author{
Paweł NowAKOwsKI \\ Independent Scholar \\ paweln3000@gmail.com
}

Recibido: 06/10/2015

Aceptado: 03/07/2016

\begin{abstract}
This chapter aims at presenting and scrutinizing a contractarian approach to libertarianism, which has been proposed by a Canadian philosopher, Jan Narveson, known as the main proponent of so-called contractarian libertarianism. The chapter begins with the short introduction followed by "Assumptions," discussing Narveson's understanding of morality, his critique of Rawlsian methodology and his view on natural law and natural rights. Afterwards, "Social contract: justification, procedure, motives" presents such elements in the philosophy of Narveson as advantages of contractarianism, levels of the social contract and its status, as well as motives of parties being subject to the social contract. The third part, entitled "Critics vs. Narveson" touches on a critical discussion of the subject by other theorists (Tibor R. Machan, John T. Sanders, Leo Groarke). The last section, "Is the Contractarianism of Narveson Libertarianism?" presents the thesis that Narveson's contractarianism is not a justified basis of libertarianism. Albeit he comes to conclusions agreeable to libertarianism, his philosophy is better labeled as laissez-faire.

Keywords: Ian Narveson, contractarianism, social contract, foundations of libertarianism.

\section{Resumen}

Este artículo se propone presentar y explorar la aproximación contractualista al libertarismo planteada por el filósofo canadiense Jan Narveson, conocido como el principal representante del llamado libertarismo contractualista. El trabajo empieza con una breve introducción seguida de un apartado que, bajo el rótulo de "Supues-
\end{abstract}


tos", discute la comprensión de Narveson de la moralidad, su crítica a la metodología de Rawls y su visión de la ley natural y los derechos naturales. Posteriormente, en el apartado "Contrato social: justificación, procedimiento, motivos" se presentan estos elementos de la filosofía de Narveson como ventajas del contractualismo, niveles del contrato social y de su estatus, y también como motivaciones de las partes sometidas al contrato social. En la tercera sección, titulada "Críticas contra Narveson", se aborda la discusión crítica sobre el tema planteada por otros teóricos (Tibor R. Machan, John T. Sanders, Leo Groarke). La última sección, “¿Es libertario el contractualismo de Narveson?" propone la tesis de que el contractualismo de Narveson no puede ser contemplado como una forma legítima de libertarismo. Pues por más que Narveson llegue a conclusiones compatibles con el libertarismo, su filosofía encajaría más bien en la categoría del laissez-faire.

Palabras clave: Ian Narveson, contractualismo, contrato social, fundamentos del libertarismo.

Ethical foundations are one of the most important problems in libertarian political philosophy. ${ }^{1}$ It may be the case because of a - not very popular among contemporary political philosophers - specific relationship between ethics and politics within libertarianism. The relationship is based on the assumption that political philosophy is a subdiscipline of ethical theory and it requires that in order to answer a political question one needs to have a clear and sound view of ethics. On the basis of which one evaluates not only interpersonal relations but also a public sphere in general. The only permissible political actions are those which meet ethical rules. Combined with a methodological and ontological individualism the libertarian approach makes politics a standard field of action which is subject to the same rules as any relation between every two (or more) human beings in a society. ${ }^{2}$

A standard libertarian view is based on natural law and natural rights theory. ${ }^{3}$ However, one of competing approaches to libertarian ethical foundations is a social contract theory which has been adopted by a Canadian philosopher, Jan Narveson. Nevertheless we need to note that he had been a utilitarian and then rejected utilitarianism under the influence of philosophy of David Gauthier and Robert Nozick. ${ }^{4}$

\footnotetext{
${ }^{1}$ I identify libertarianism with so called deontological libertarianism and regard consequentialist argumentation as non essential to this political philosophy.

${ }^{2}$ See e.g. M. N. Rothbard, The Ethics of Liberty, New York, New York University Press, 1998, and idem, For a New Liberty. The Libertarian Manifesto, Second Edition, Auburn, Alabama, Ludwig von Mises Institute, 2006.

${ }^{3}$ For elaboration see ibidem; see also J. Narveson, The Libertarian Idea, Broadview Press, Peterborough, Ontario, 2001, p. 109, 193.

${ }^{4}$ See ibidem, p. XI.
} 
Narveson is pegged as one of the most important figures in a libertarian movement, ${ }^{5}$ but his contractarian proposal which can be precisely termed "market contractarianism", ${ }^{6}$ is very far from being a representative basis of libertarianism. Thus, it seems legitimate to scrutinize his novel approach and answer the question raised in the subtitle of this chapter, namely: is it still libertarianism? The question will be answered in the final section of the chapter.

\section{Assumptions}

In his best-known book, The Libertarian Idea, Narveson takes on the crucial question of what are the foundations of libertarianism. ${ }^{7}$ But his endeavour goes beyond those foundations: "We want a really fundamental answer to the question why one should embrace, accept, adopt, or pay attention to any moral requirements, principles, or concerns" — - he states.

How does he define morality? Thusly: "the normative question of general relations among people: how we are to relate to our fellows"; "a set of internally monitored controls on one's behaviour as it relates to other people"; 10 "a regime of interpersonal behavioural control" 11 ; "a set of requirements that will make us all better off if they are met by everyone - and that, accordingly, are liable to the problem of defection by some who will try to take the money and run". ${ }^{12}$ According to John T. Sanders, ${ }^{13}$ Narveson believes that morality appears only when there is social interaction, opposed to what modern philosophers call the state of nature. Sander's view is in line with the definitions cited above, but we must specify that Narveson also uses a notion of personal morality which he defines as "the area of decisions about how one is to run one's life, the ultimate bases on which one will make one's choices". ${ }^{14}$ He claims that the personal sense of the

\footnotetext{
${ }^{5}$ Cf. D. M. Hausman, M. S. McPherson, Economic Analysis, Moral Philosophy and Public Policy, New York, Cambridge University Press, 2006, p. 168; P. Vallentyne, Libertarianism, 2010, retrieved 24 August 2012 from: http://plato.stanford.edu/entries/libertarianism/, 20. 07. 2010.

${ }^{6}$ See S. Wein, "Reconciling Radicals: Market Contractarianism and Fundamentalist Utilitarianism", in M. Murray (ed.), Liberty, Games and Contracts. Jan Narveson and the Defence of Libertarianism, Bodmin, Cornwall, Ashgate, 2007, pp. 201-202.

${ }^{7}$ See J. Narveson, op. cit., p. 105.

${ }^{8}$ Ibidem, p. 107.

${ }^{9}$ Ibidem, p. 105.

${ }^{10}$ Idem, "Contracting for Liberty", in T. R. Machan, D. B. Rasmussen (ed.), Liberty for the TwentyFirst Century. Contemporary Libertarian Thought, Boston-London, Rowman \& Littlefield, 1995, p. 21.

${ }^{11}$ Idem, Social Contract, Game Theory and Liberty: Responding to My Critics, in M. Murray (ed.), op. cit., p. 238.

${ }^{12}$ Idem, The Libertarian Idea, op. cit., p. 146.

${ }^{13}$ J. T. Sanders, "Contracting Justice", in M. Murray (ed.), op. cit., p. 22.

${ }^{14}$ J. Narveson, The Libertarian Idea, op. cit., p. 123.
} 
term "morality" includes its social meaning. Hence, personal morality is broader than social morality.

Social morality is subject to "some rational constraints". "In the social sense, morality is quite essential for the governance of people in general — of "society»" he adds. ${ }^{16}$ Insofar as a personal sense of morality is left up to a sovereign subject, the shape of the sort of morality regulating social issues requires referring to the community. According to Narveson, rules regarding society are determined by the values of individual people. In that case, he claims, the only possibility is that "those individual values support those social principles". ${ }^{17}$

Social morality is implicit in personal morality, thus the actor is bound by social morality, so he is not confined to the individualism of personal morality. ${ }^{18} \mathrm{In}$ Narveson's opinion the basis of morality is one's own interest, and this implies that interests of the bargaining subjects constitute the basis of the social contract. ${ }^{19}$

It should be also noted that the philosopher distinguishes a group of "liberal interests". Their characteristic is that they are not designed to make anyone unsatisfied, therefore Narveson does not find any reason to object the pursuit of them. Indeed, he argues that through free exchange, pursuing one's own satisfaction improves the situation of the other as well. Voluntary exchange is the optimal social institution since it maximizes the benefits gained by society. ${ }^{20}$ His position is characteristic to libertarianism and laissez faire (a radical free-market approach), nevertheless he uses this sort of argumentation not only to justify institution of contract, but the libertarian political philosophy in general.

In making his case, Narveson comments on positions of other philosophers who work in an intellectual tradition close to his own paradigm, i.e. of John Rawls, Thomas Hobbes and David Gauthier. He is highly inspired by the works of Hobbes and Gauthier, especially the latter, since Narveson adopts a similar view and uses it to present a novel approach to the foundations of libertarianism. ${ }^{21} \mathrm{He}$ also accepts the standpoint of Hobbes that morality appears out of moral chaos (based on a reasoning of Vilfredo Pareto). ${ }^{22}$ The Canadian philosopher points out that: "The genius

\footnotetext{
${ }^{15}$ Ibidem.

${ }^{16}$ Ibidem.

${ }^{17}$ Ibidem, pp. 167; 123-125.

${ }^{18}$ See ibidem, pp. $167-168$.

${ }^{19}$ Idem, Contracting for Liberty, op. cit., p. 32; idem, The Libertarian Idea, op. cit., p. 135, 146.

${ }^{20}$ Idem, Contracting for Liberty, op. cit., p. 33; see also E. J. Bond, "Some Remarks on the Foundations of Libertarianism", in M. Murray (ed.), op. cit., p. 11. We also need to note that, according to Narveson, a basis of morality is a game theory (J. Narveson, Social Contract..., op. cit., p. 222). However, this problem is not important for the aims of this chapter.

${ }^{21}$ See idem, The Libertarian Idea, op. cit., pp. XII-XIII.

${ }^{22}$ Idem, "Why Liberty?", in T. Gizbert-Studnicki, M. Klinowski (eds.), Law, liberty, morality and rights. 23rd World Congress of Legal and Social Philosophy 2007, Cracow, Wolters Kluwer Polska, Warszawa, 2010, p. 306.
} 
of Hobbes lies in the fact that he shows how politics is needed even if none of the interests at the ground-floor level are themselves political". ${ }^{23}$ Finally, Narveson refers to the Prisoner's Dilemma and sums up that his position is somewhere between the view of Hobbes who proposes an institution of sovereign as a supervisor of cooperation of individuals, and of Gauthier who emphasizes a tendency of individuals to cooperation. Narveson accepts the view of Gauthier who presents a "constrained maximization" which is opposite to "straight maximization" — being a disposition to thievery. He also argues that Hobbes's idea of creating government is illogical. ${ }^{24}$

When it comes to Rawls he becomes critical, although not because of Rawl's anti-capitalist conclusions, since Narveson only addresses the stricte contractarian methodological aspect of the theory. ${ }^{25}$ In The Libertarian Idea he focuses on the Rawlsian notion of a "veil of ignorance" and claims that there are two kinds: "theoretically dispensable" and "theoretically indispensable." The first is about universalism, and the second touches on impartiality and holds it as not the only feature of justice since it should also feature within individuals. ${ }^{26}$ The philosopher rejects the second, strong kind of "veil". ${ }^{27} \mathrm{He}$ suggests that the approach of Rawls, which does not imply an existence of particular self-conscious individuals, ${ }^{28}$ is an intuitionist view and that it overlooks the aspect of contractarianism which Narveson is most interested in, namely what the "veil of ignorance" should be replaced with. ${ }^{29}$ Here is the starting point in his search for a foundation for political theory.

Narveson rejects all moral theories based on intuition. He regards appealing to moral intuitions as not rational and claims that the intuitionist view makes rational agreement impossible. ${ }^{30}$ The rejection of intuition also applies to libertarians who defend natural rights. ${ }^{31}$ It should be noted that Narveson seems to regard an appeal to intuition the sine qua non of natural law and natural rights. He proposes a contractarian approach in place of an "intuitionist" view, rather than the "natural rights" view. $^{32}$

Narveson's standpoint on natural law and natural rights theory should be presented more precisely. On the one hand he assumes that different people can have different opinions on what is the basic rule of human nature and that this is implied

\footnotetext{
${ }^{23}$ Idem, The Libertarian Idea, op. cit. p. 166.

${ }^{24}$ Ibidem, pp. 139-143.

${ }^{25}$ Cf. P. Przybysz, Modele teoretyczne w współczesnej filozofii politycznej liberalizmu, Poznań, Wyd. Naukowe Uniwersytetu im. Adama Mickiewicza, 2009.

${ }^{26}$ J. Narveson, The Libertarian Idea, op. cit., p. 13.

${ }^{27}$ Ibidem, pp. 133-134.

${ }^{28}$ It should be noted that this thesis is strongly polemic.

${ }^{29}$ Ibidem, p. 156.

${ }^{30}$ See ibidem: p. XI, 109, 122; broadly on Narveson's claims on intuitionism see ibidem, pp. 108-121.

${ }^{31}$ Ibidem, p. XI, 56, 109.

${ }^{32}$ Ibidem, p. XIII.
} 
by the possibility of adhering to different ethical systems. The above is the reason why he associates natural law with intuitionism and rejects it. He emphasizes an instrumental character of morals, pointing out that it needs to be attractive to people and criticizing natural rights theorists for disregarding it. Furthermore he notes that "the claim that some view is «based on the nature of things» or on «human nature» is unclear. Talk of «conforming to nature» makes no literal sense; nature simply is. It sets limits to what is possible, but can prescribe nothing". ${ }^{33} \mathrm{He}$ also claims that neither St. Thomas Aquinas nor John Locke did clarify what the natural law is. ${ }^{34}$ Additionally, he finds it ironic that even among theorists appealing to natural rights theory we can observe significant differences. ${ }^{35}$ However, it is worth to notice that such a critique of the theory was persuasively rejected by Murray N. Rothbard who pointed out that ceasing to study a natural law theory because of different propositions made by some thinkers would be an absurdity. ${ }^{36}$

Nevertheless, Narveson does not dissent from natural law theory completely. $\mathrm{He}$ argues that contractarianism can be merged with one kind of it. ${ }^{37}$ According to him, "a natural law theory should say, in the end, that in view of the way things and people are, subscribing to this set of rules or virtues is our best means of accommodating them". ${ }^{38}$ In effect, the philosopher tries to bridge his contractarian idea and the natural law claiming that some rule or value can be described as "natural," when it is the best rational solution ${ }^{39}$ which can be found by a concrete person in a concrete situation. He refers to Hobbes in this matter, ${ }^{40}$ but we can also perceive here a view of a German thinker, Samuel Pufendorf who regarded a social contract as directly implied by natural law. In Narveson's opinion, law could be defined as natural because of the fact of being "acknowledged, recognized, or employed implicitly as a canon of interpersonal criticism of behavior". ${ }^{41}$ Thus, he claims that we could define as natural some parts of game theory used in the contractarian approach such as famous Prisoner's Dilemma. ${ }^{42}$

However, when it comes to libertarianism, the most important aspect of the theory derived from human nature is not just natural law, but rights stemming from it,

\footnotetext{
${ }^{33}$ Idem, Contracting for Liberty, op. cit., p. 20. In these words Narveson refers to a famous "Hume's guillotine" and so called the "is-ought" problem.

${ }^{34}$ Idem, The Libertarian Idea, op. cit., pp. 149-150.

${ }^{35}$ Idem, Why Liberty?, op. cit., pp. 298-299; see also idem, The Libertarian Idea, op. cit., p. 44, 109.

${ }^{36}$ See M. N. Rothbard, The Ethics of..., op. cit., pp. 10-11.

${ }^{37}$ J. Narveson, Contracting for Liberty, op. cit., p. 20.

${ }^{38}$ Ibidem.

${ }^{39}$ In a Weberian sense of a goal-oriented rational action in the compliance with game theory.

${ }^{40}$ Ibidem. As a philosopher who appeals to Hobbes and Locke, Narveson is very interested in the idea of the state of nature which he touches on repeatedly.

${ }^{41}$ Ibidem, pp. 149-150.

42 On this see M. Modrzejewska, Libertariańskie koncepcje jednostki i państwa we wspótczesnej amerykańskiej myśli politycznej, Kraków, Wyd. UJ, 2010, pp. 112-115.
} 
that is, natural rights. It is this crucial idea of libertarianism which Narveson regards as intuitionist, hence flawed. ${ }^{43}$

On the one hand Narveson mentions that he finally remains unconvinced of the validity of the idea of natural law, ${ }^{44}$ but on the other hand he argues in the context of the Prisoner's Dilemma:

Wherever the structure of preferences of the different parties is clear to both parties (and it is not always), we have a basis for a rule of precisely that kind: a natural basis for a moral rule, in fact. (...) So understood, we may accept the idea of natural law nearly enough. What its relation to political structures may be is, of course, another question, and the main question dealt with in this book. ${ }^{45}$

Hence, although Narveson does not value a natural law intuition, he seems to endeavour to gain acceptance even of that group of thinkers whose paradigm is the natural law theory. He also touches on the field while considering an agreement preceding a social contract establishing a free-market order. The aim of this "prior agreement" is to establish property rights and "this fundamental agreement can reasonably also be held to consist in the determination of «natural» rights". ${ }^{46}$ As we can see, Narveson mentions here not the natural law, but natural rights. However, we should not forget that in his opinion cognition of rights is not a task of "sound reason," but that they are subject to a contractarian procedure, hence they cannot be described as natural in a strict sense.

It seems then that in Narveson's theory there is only one natural law: a contract leading to a social order implied by the "Liberty Principle." So it is an impersonal law, and Narveson's assumption is a kind of "impersonal egoism" which we can also find in the capitalist philosophy of Eric Mack. ${ }^{47}$ This idea reads that objectively everyone follows their own interest and by using instrumental rationality should (if they understand that "the Liberty Principle" is optimally best for each and every person) enter into agreement constituting laissez-faire capitalism. Thus egoism is to be an anthropological aspect of natural law a la Narveson.

\section{Social contract: justification, procedure, motives}

Narveson adopts contractarianism as a starting point for establishing a social order, because of an obvious observation that people opt for different ethical doctrines.

\footnotetext{
${ }^{43}$ See J. Narveson, The Libertarian Idea, op. cit., p. 56.

${ }^{44}$ Ibidem, p. 150.

${ }^{45}$ Ibidem; see also ibidem, p. 198.

${ }^{46}$ Ibidem, p. 193.

${ }^{47}$ See D. Gordon, "Contemporary Currents in Libertarian Political Philosophy", in Literature of Liberty. A Review of Contemporary Liberal Thought, 4, 1 (Spring), 1981, pp. 16-20.
} 
He is interested in such an arrangement of social institutions that excludes coercion, that is, an arrangement that could be accepted by everyone. ${ }^{48}$ Thus the most important advantage of contractarianism is that it is aimed at "generat[ing] moral principles for societies out of the nonmoral values of individuals". ${ }^{49}$

Narveson argues that actions of some people are not always valuable from the point of view of others. A rational approach to this matter is to consider the way of affecting a conjuncture so that acts of some people against acts of others were as positive as possible (or at least just neutral). Recognizing an act as positive depends on one's attitude towards the ends of everybody else. The point is that everyone could enjoy the highest level of liberty. We cannot just ignore people choosing ends in opposition to the ends of their fellowmen, because we cannot remain indifferent to, for example, a knife attack. Possible responses may include trickery or force.$^{50}$ Then "the agent takes the other persons in his environment as fixed entities, not amenable to rational influence" ${ }^{51}$ As an alternative Narveson presents a "strategic" approach which he describes as follows: "we attempt to improve the situation by establishing some kind of communication with the other parties, in the course of which we supply information to them about our likely response to possible actions of theirs, and they in turn communicate an intention to respond to your response in one way or another". ${ }^{52} \mathrm{He}$ justifies it with a quotation from Hobbes: "as to strength of body, the weakest hath enough to kill the strongest". ${ }^{53}$

But choosing a particular "strategy" proves to be a far more difficult task. There are two sorts of strategies. The first is based on using or threatening force in order to influence someone's actions - the strategy of the stick. While the second is the strategy of the carrot which means that one person announces that he will perform an action that is favourable to another person, if that person chooses to act in a way which is more beneficial to the proponent. ${ }^{54}$ According to Narveson, choosing the first strategy requires hostility toward all encountered people. Appealing to the carrot is a demonstration of being open to beneficial or at least neutral relations with others. Narveson emphasizes that the first strategy does not fit libertarianism. ${ }^{55}$ A crucial aspect of a social contract is mutuality ${ }^{56}$ - a Hobbesian manner of reasoning.

\footnotetext{
${ }^{48}$ J. Narveson, Why Liberty?, op. cit., pp. 298-300.

${ }^{49}$ Idem, The Libertarian Idea, op. cit., p. 167.

${ }^{50}$ Idem, Contracting for Liberty, op. cit., pp. 21-23.

${ }^{51}$ Ibidem, p. 22.

52 Ibidem.

${ }^{53}$ Quoted in ibidem.

${ }^{54}$ However, what stays unsolved is the problem of negative externalities (I am indebted to Danny Frederick for this point).

${ }^{55}$ Ibidem, pp. 22-23.

${ }^{56}$ See J. T. Sanders, op. cit., p. 22.
} 
The ideas of the Canadian philosopher are structured in a formal contractarian procedure which consists of two levels. The first is the assumption that individuals who are members of a given community (Narveson uses a rather inadequate notion of "polis") vary in values and try to justify them. The difference in opinions of particular individuals on values underlies a need of morals and/or politics to come to existence. The second part of the contractarian procedure is stricter than the first. It requires the values of the individuals not to be a barrier to the possibility of cooperation - a requirement that is not always fulfilled. Where which there is no place for politics, instead there is violence, chaos and war. ${ }^{57}$

It appears to be for this reason that Narveson raises a necessity of the aforementioned "prior agreement" or "pre-market bargaining" (which notion he takes from Jules Coleman). It is about a conventional establishing or regularizing an institution of private property which is the basis of justice. Following John Gray, he regards this approach as a representative for a Hobbesian style contractarianism, ${ }^{58}$ but in this respect we can also observe a similarity to, for example, David Hume. According to Hume, establishing property rights is a basis of justice, and these rights, and hence justice itself, are conventional matters.

We should also draw attention to the relation between a social contract and a contract as such. Both involve "the reciprocal conditionalizing of behavior" and oblige those who are the subjects of the contract. ${ }^{59}$ However, the most important is that a "social contract" (Narveson himself uses inverted commas) is "an unspoken understanding, a non-negotiated agreement-an agreement in action, not in words nor preceded by words". ${ }^{60}$ Narveson also clearly dissents from the idea that a social contract is the historical origin of the state. ${ }^{61}$ "The Grand Social Contract is, obviously, a model or idealisation of some kind"- he writes. ${ }^{62}$ Thus the philosopher is one of those contractarian theorists who use the social contract theory in a broader, not literal, sense. ${ }^{63}$ Jean Hampton describes them in these words: "Hence, thinking about 'what we could all agree to' allows us to construct a deduction of practical reason to determine what policies are mutually advantageous" ${ }^{64}$ It is in full consonance with the approach of Narveson.

Considering the way of "concluding" a "contract" in such a form, the author of The Libertarian Idea claims: "Each party [of a contract] adopts a disposition to

\footnotetext{
${ }^{57}$ J. Narveson, The Libertarian Idea, op. cit., p. 164.

${ }^{58}$ Ibidem, p. 193.

${ }^{59}$ Idem, Contracting for Liberty, op. cit., p. 25.

${ }^{60}$ Ibidem.

${ }^{61}$ Idem, The Libertarian Idea, op. cit., p. 132.

${ }^{62}$ As quoted in J. T. Sanders, op. cit., p. 21.

${ }^{63}$ See J. Hampton, "Contract and Consent", in R. E. Goodin, P. Pettit, T. Pogge (eds.), A Companion to Contemporary Political Philosophy, vol. II, 2nd Edition, Blackwell Publishing, 2007, pp. 482-483.

${ }^{64}$ Ibidem, p. 484; see also J. T. Sanders, op. cit., p. 25.
} 
respond in ways that make the resulting interaction mutually preferable to its alternatives. Such dispositions are moral virtues (...). But the contractarian view differs from theories claiming to found morals on a prior discernment of what is virtuous, independently of interaction". 65

Since virtue is a particular disposition, i.e. a behavioural element of an attitude of a subject ${ }^{66}$, it means that he or she is possesses a virtue as far back as on a level of thinking, what in some measure shifts the burden of bravery from an act to a disposition. It is a quite uncommon approach to the case of virtue. Narveson also claims that a virtuousness of this disposition is not known a priori, but a posteriori.$^{67}$ Thus, he must aim at underlying the difference between his contractarianism, which is to be persuasive to all because of its profitability, and the position of "intuitionists" who - as Narveson believes - develop some patterns of virtuous action, but lack the justification which could convince everyone.

$\mathrm{He}$ also points out that the contractarian theory is not restricted to the theory of enforceable duties, that is, of narrowly understood justice. He argues that when people choose the aforementioned strategy of the carrot in the case of welfare, they equally choose promoting welfare of everyone else. It is a public attitude which nevertheless is not very costly. "We do not take on a great burden when we agree that (...) it is a better thing that Jones or Smith do well than badly, and to be disposed - but not conscripted - to lend an occasional hand or an occasional dollar if need be" ${ }^{68}$ One can read these words as an encouragement to something like an altruistic ethos in a free market institutional order.

An important part of Narveson's argumentation is the problem of motives for becoming a part of a social contract. He states succinctly: "The social contract proposal is that it is worth paying the price of nonviolence toward others in return for nonviolence from them" ${ }^{69}$ The most important thing about contractarianism is to derive such a proposal that everyone could reasonably agree to. ${ }^{70}$ Such an offer is "the Liberty Principle" which is "the best moral outlook from the point of view of Everyman". "What makes it best, I claim, is that this is the principle that could rationally be expected to maximize the individual's return from society, as it were. Libertarianism incurs the least costs of such theories, and makes possible the greatest benefit"- claims Narveson. ${ }^{72}$

\footnotetext{
${ }^{65}$ J. Narveson, Contracting for Liberty, op. cit., p. 25.

${ }^{66}$ See E. Aronson, T. D. Wilson, R. M. Akert, Social Psychology, 8th Edition, Cloth, Pearson, 2013, chapter 7.

${ }^{67}$ J. Narveson, Contracting for Liberty, op. cit., p. 25.

${ }^{68}$ Ibidem, pp. 37-38.

${ }^{69}$ Idem, Why Liberty?, op. cit., p. 309.

${ }^{70}$ Ibidem, p. 310; idem, The Libertarian Idea, op. cit., p. 132.

${ }^{71}$ Idem, Why Liberty?, op. cit., p. 299.

${ }^{72}$ Ibidem.
} 
In The Libertarian Idea he confidently argues that any other approach to morality cannot reconcile people who opt for various ideas of individual good. However everybody needs morality, for everybody can be robbed and cooperation with others is beneficial for everyone. ${ }^{73}$ Therefore, a mutual benefit consists in a rejection of using force while pursuing our ends and in guarantying a social consolidation of a value of interpersonal agreements. Narveson emphasizes that expecting others to meet those conditions is rational and so is the very commitment. ${ }^{74} \mathrm{~A}$ contract meets a condition of rationality when it is oriented on improving a situation of all parts thereof. The same goes for a general rule, regulating social relations-when it is aimed at benefiting all, its adoption is justified. ${ }^{75}$

But what is the way of adopting this regulative rule? Narveson opts for an arranged morality, a deliberate morality which is to be established by the use of reason. ${ }^{76}$ Crucially, he states that his idea of morality can be accepted only by those who are rational themselves. ${ }^{77}$ What about the rest? He appeals to Hobbes and answers that when somebody does not want to "accede" to the social contract, the others cannot do anything. "If in the process they end up on the gallows or in the tar-pit, that's tough for them- but it is not unjust". ${ }^{78}$

But does contractarian technique assure adopting "the Libertarian Principle"? In Narveson's opinion, it does. He argues that to answer this question, we need to realize that: firstly, a social contract is adopted voluntarily; secondly, "the idea of libertarianism is to maximize individual freedom by accounting each person's person as that person's own property, that is, by giving each person the maximal level of rights to the disposition of that particular bit of «property» (...)". ${ }^{79}$ Narveson believes that supporting libertarianism should be of a prima facie character and that one cannot dispute the necessary libertarian implications of the social contract (Narveson deals with the problem in detail in the third part of The Libertarian Idea) ${ }^{80}$ Contractarian libertarianism (or libertarian contractarianism) lies in adopting a universal social contract that allows pursuing one's own ends without using force in relations with others. ${ }^{81}$ One can conclude that the contract becomes an objectivised structure which affects individual choices and thereby loses its intrapersonal sense, and becomes an impersonal (structured) force affecting relations between people.

\footnotetext{
${ }^{73}$ Idem, The Libertarian Idea, op. cit., p. 149.

${ }^{74}$ Idem, Contracting for Liberty, op. cit., p. 24.

${ }^{75}$ Ibidem, p. 30.

${ }^{76}$ Idem, The Libertarian Idea, op. cit., pp. 125-126.

${ }^{77}$ Idem, Contracting for Liberty, op. cit., p. 25.

${ }^{78}$ Ibidem, p. 23.

${ }^{79}$ Idem, The Libertarian Idea, op. cit., p. 176.

${ }^{80}$ Ibidem, p. 177.

${ }^{81}$ Idem, Contracting for Liberty, op. cit., pp. 25-26.
} 


\section{Critics vs. Narveson}

Although Narveson is not an unknown author, his writing has not been widely discussed so far. However, there is one exception which is his festschrift. ${ }^{82}$ Against possible suppositions that such a form is not a good opportunity to criticize ideas of an academic to whom the festschrift is dedicated, in this case analyses of Narveson's work do not differ from standard philosophical or scientific analyses. Indeed, the volume consists of response of the author of The Libertarian Idea, and owing to this an explicit philosophical discourse is created. Some of the chapters correspond with problems of this chapter, hence it seems worth to point out some remarks of commentators.

Tibor R. Machan criticizes the very basis of Narveson's project which means he deflates a social contract as a valid source of morality. Being a proponent of a teleological natural rights theory ${ }^{83}$, Machan argues that a "social compact" ${ }^{84}$ does not suffice. He believes that an agreement proposed by contractarians must be preceded by referring to logically prior ethical principles which are not a matter of convention; or to an idea of natural drives of human being, such as, for example, self-preservation. ${ }^{85}$ Moreover, if we believe that human beings have some common features, for example, that they are "sovereign agents and their agency is a precondition of a moral life," then the features cannot appear only as a consequence of a social contract. It is a contract what must be concluded according to those assumptions, not vice versa. ${ }^{86}$ In this context Machan also touches on the another problem. He states: "[N] othing follows from everyone concerned promising to abide by some guidelines unless promises themselves have normative significance. And this cannot derive from a still prior compact, ad infinitum". ${ }^{87}$ Another serious objection is that an irrational social contract is not morally binding ${ }^{88}$ Thus rules adopted in a social agreement are not necessarily morally binding. "[W] ho would morally blame someone who (...) decided to violate the norms of the Nazi Party?" - he asks rhetorically ${ }^{89} \mathrm{He}$ also points out that it is Narveson who requires parties of a contract to possess a feature of reasonability, but then - as Machan shows - in the case of an agreement as such,

\footnotetext{
${ }^{82}$ See M. Murray, op. cit.

${ }^{83}$ See e.g. T. R. Machan, “Are Teleological Rights Theories Utilitarian”, Cato Journal 7, 1 (spring/ summer), 1987.

${ }^{84}$ He prefers this term to a "social contract"; see more in idem, "Is Agreement Enough?", in M. Murray (ed.), op. cit.

${ }^{85}$ Ibidem, p. 33; cf. W. Kymlicka, "The Social Contract Tradition", in P. Singer (ed.), A Companion to Ethics, Oxford, Wiley-Blackwell, 1993, pp. 186-188.

${ }^{86}$ T. R. Machan, Is Agreement Enough?, op. cit., pp. 38-39.

${ }^{87}$ Ibidem, p. 33.

${ }^{88}$ Ibidem, p. 34.

${ }^{89}$ Ibidem, p. 35.
} 
including a social contract, this normative requirement does not form a constitutive attribute. ${ }^{90}$ Machan is against scorning (writing off) those who would turn out not to be reasonable/rational to take part in a tacit social contract. ${ }^{91} \mathrm{He}$ is prone to recognize as justified an enlightenment variant of a social contract instead of that which has been developed since the nineteenth century and which Narveson argues for. ${ }^{92}$

Responding to this critique, Narveson ${ }^{93}$ argues that every contract implies an obligation of obeying it, but it is in contradiction with his view in The Libertarian Idea. For in his most important work he is far closer to the position of Machan. Appealing to David Hume, he admits that the very giving one's word does not imply a normativeness of a contract. As he states: "To account for the obligation to keep promises on the basis of a general promise to do so seems, shall we say, unpromising". ${ }^{94} \mathrm{Nev}$ ertheless Narveson tries to extricate from this problematic situation by pointing out that the contract he proposes is not a literal one. ${ }^{95}$ However, we should regard this position as an unclear methodological quibble which does not solve the problem, for Narveson still does not give the answer for the question of the basis of normative validity of a contract. Nevertheless, the situation changes if we recognize, that despite the fact that Narveson does not raise it in his response for Machan's critique, he does introduce an anthropological idea of the man's pursuit of self-preservation ${ }^{96}$ which, according to Machan, is enough to recognize the validity of the contractarian theory of agreement.

On the other hand, Machan is right in opposing Narveson's requirement of reasonability/rationality. The objection will be of a fundamental importance in an adjudication of the philosophy of the Canadian thinker from a libertarian perspective.

Another critical view which corresponds with the subject of this chapter is presented by Sanders (who has already been cited above). He faults Narveson for similar mistakes which Narveson himself addresses to Rawls. The point is duplicating the approach of Rawls in ignoring "particular humans in particular circumstances" ${ }^{197}$ within the contractarian framework. Also Leo Groarke ${ }^{98}$ criticizes Narveson for adopting a similar approach to Rawls in respect of making an unreal assumption

\footnotetext{
${ }^{90}$ Ibidem, p. 40.

${ }^{91}$ Ibidem, pp. 40-41; 45 n. 26.

${ }^{92}$ See W. Kymlicka, op. cit., pp. 186-188.

${ }^{93}$ J. Narveson, Social Contract..., op. cit., p. 220.

${ }^{94}$ Idem, The Libertarian Idea, op. cit., p. 132; cf. M. N. Rothbard, The Ethics of..., op. cit., pp. 79-80; H.-H. Hoppe, "The Role of Intellectuals and Anti-Intellectual Intellectuals", in idem, The Great Fiction. Property, Economy, Society, and the Politics of Decline, Baltimore, Maryland, Laissez Faire Books, 2012.

${ }^{95}$ J. Narveson, The Libertarian Idea, op. cit., p. 132.

${ }^{96}$ Ibidem, p. 147.

${ }^{97}$ J. T. Sanders, op.cit., p. 29.

${ }^{98}$ L. Groarke, "Does Scepticism Beget Libertarianism? A Response to Narveson on Reason, Morality and Politics", in M. Murray (ed.), op. cit.
} 
on the original position. Groarke defends moral intuitions of people and opposes the requirement of forgoing those intuitions within a contractarian procedure. $\mathrm{He}$ promotes a different contractarian theory which would enable people to keep their intuitions and beliefs, being the source of their identities.

Narveson responds that it is impossible to take into consideration both the interests and the moral views of actors, since the moral views are incomparable. ${ }^{99}$ Groarke does not assume that they are, yet he sees a chance for a compromise. Anyway, Narveson does not. Groarke asks, "whether individuals who have convictions founded on strong moral and/or political intuitions should feel compelled to accept the conditions of the contract-making situation which Narveson proposes". ${ }^{100} \mathrm{He}$ incisively argues that libertarians-intuitionists could adopt the aforementioned proposal, provided that they would find it convincing. Indeed, he rightly points that then they would not be "true Narvesonians," since they would hold their intuitions and would agree with Narveson only in terms of a political order (prescinding here from differences between anarchocapitalism and minarchism). Nevertheless, he is prone to believe that if libertarians recognize that Narveson's proposal based on rational self-interest does not lead to laissez faire, then they would confine themselves to their intuitions. It seems trivial, but as is often in philosophy this seeming triviality underlies a strong thesis: "it is these intuitions, not an appeal to rational self-interest which is the real basis of libertarianism". ${ }^{101}$

We can quote a standpoint of - as Narveson would say - a libertarian-intuitionist, Machan: "[I]t is not sufficient to learn of the true principles of justice; it is also vital to apply them, and that would not be possible without widespread agreement - namely, a social compact or contract". ${ }^{102} \mathrm{He}$ conceives contractarianism only as a tool stabilizing a political order, and not as its philosophical foundation. For this is the role of natural law. A social contract which Machan admits can be associated with the third stage of contractarianism in the theory of German thinker Samuel Pufendorf. After establishing that society is a subject of rights and choosing a political system, he expected society to voluntarily subject to the rule of the government. This is what we can say about libertarians' possible acceptance of a contractarian proposal. As regards supporters of other moral views, Groarke is very sceptical, since contractarianism of Narveson requires very much from those people. ${ }^{103}$

However, does Narveson indeed, as Groarke believes, require from people to forgo their intuitions? Does this postulate concern an impoverishment of their identity? A positive answer to these questions would be wrong. Answering the objections,

\footnotetext{
${ }^{99}$ J. Narveson, Social Contract..., op. cit., p. 222.

${ }^{100}$ L. Groarke, op. cit., pp. 51-52.

${ }^{101}$ Ibidem, p. 52.

${ }^{102}$ T. R. Machan, Is Agreement Enough?, op. cit., p. 44.

${ }^{103}$ L. Groarke, op. cit., p. 52.
} 
Narveson ${ }^{104}$ points out: "On the contrary: accepting people as they are is the beginning of wisdom in this business". Of course, in the following sentences we can read again that taking into consideration not only interests, but also individual intuitions, is not feasible. ${ }^{105}$ Nevertheless, it does not mean that people are to forget their intuitions. Narveson does not mean an individual life of a man, but the basics of a political order. Not a personal morality, but a social one. He proposes to establish the latter contractually and only in this regard he proposes forgoing moral intuitions which interfere with views of others and which would interfere with a possible agreement of each and every contractor on a political system (on a common social morality). $\mathrm{He}$ tries to object a possible situation that one person could try to impose his or her intuitions on that matter on the other person and vice versa. Thus, you can be yourself fully, you can fully realize your subjectivity, provided that you do it outside social issues, outside a political system, hence in a sphere which is free from coercion. It is about the aforementioned liberal interests. Generally speaking it is then about Herbert Spencer's "Law of Equal Freedom." As Narveson argues: "Contractarianism claims to find a basis in everyone's practical reason for accepting a set of norms calling for restriction on people's activities in pursuit of their various values" ${ }^{106}$ Hence, a reconciliation of different intuitions is impossible in the area of politics (and morality - regarding so called social morality), where one needs to ultimately adopt some particular standpoint underlying an institutional, political order. According to conditions of a contract one can freely realize all of one's moral intuitions regarding the individual sphere of life and that part of interpersonal relations which is free of interference by a coercive apparatus. Therefore, in a response to remarks of Groarke, Narveson states that no other idea, apart from the libertarian one - as he understands it-promotes "humanity" as much, which is due to the fundamental importance of liberty of the individual conceived of as the maximum liberty of the individual while protecting equal liberty for the rest. He firmly rejects Groarke's objection that he promotes a "narrow and constricted" approach to human nature. ${ }^{107}$ Narveson's explanations enable us to recognize objections of the critic as to some extent irrelevant, but there is no doubt that the issues are still open to the discussion.

Nevertheless, it seems that Groarke is right when he doubts such a high inclusive potential of Narveson's contractarianism which the Canadian theorist attributes to it. Even if everyone is ready to forgo their intuitions (while deliberating the contract), what about their views which they regard as non-intuitionist and objective? Or, views fulfilling epistemological conditions, e.g. intersubjective communication and intersubjective verification? The question replaces the emphasis on intuitionism

\footnotetext{
${ }^{104}$ J. Narveson, Social Contract..., op. cit., p. 222.

${ }^{105}$ Ibidem.

${ }^{106}$ Ibidem.

${ }^{107}$ Ibidem.
} 
as a meta-ethical standpoint in a broader, epistemological sense. We should keep in mind that there are different philosophical doctrines or, to speak narrower, epistemological ones which are supported by some authors who additionally receive wide recognition. What about solipsists, methodological collectivists, Hegelists? What about supporters of a myth in Georges Sorel's variant? Or, libertarian adherents of natural rights and/or apriorists-deductionists who consider self-ownership (or even the right to self-ownership) as certain as night follows day? They themselves could regard Narveson's ideas as intuitionist, just like he does regarding their ideas. Hence, from a point of view of at least some theorists, it could be Narveson who may be called on to forgo his - as they could also say-intuitions. It is then a mistake to ignore the fact that there are different ontological and epistemological standpoints in philosophy. It may be impossible to get everybody to believe that all views except Narveson's are intuitionist, that is, in principle worse and deserving relinquishment, subjective. Moreover, it is worth to quote a philosopher of science, Monika Walczak, who points out with reference to Stanisław Judycki: "They attribute to an aprioristic factor of intuition such functions of cognition as: understanding (a content) of terms, understanding propositional contents (judgements), identifying relations of sense, grasping different relations (including those between judgements) or an intellectual perceiving value of something — all such acts of reason are called intuitional acts". ${ }^{108}$ Thus an intuition is connected with apriorism not more than with any other epistemological standpoint. ${ }^{109}$

Even forgoing one's intuitions during a contractarian procedure is not a guarantee of consensus. Since there is ethical pluralism (Narveson opts for relativism in personal morality), there is also pluralism in the field of epistemology, ontology or anthropology. It is not only ethics where we differ. Our differences extend to other philosophical issues which Narveson implicitly assumes as unquestionable.

As quoted above, Groarke objects the requirement of forgoing intuitions and beliefs. According to Narveson, a belief is indeed an intuition. And if his own beliefs are not intuitions, what are they? He seems to argue: "when you claim something, what I do not, your view is intuitionist, so it should be forgone. Instead, what I claim is not an intuition, it is the truth". Thereby he runs the risk of being perceived in relations with other philosophers (except Gauthier, Hobbes and, perhaps, a few others) as the philosopher among the prisoners of Plato's cave.

\footnotetext{
${ }^{108}$ M. Walczak, "Aprioryzm i intuicja”, in G. Żurkowska, S. Blandzki (eds.), Rezonujący rozum nauki a rozumność intuicji, Nowa Wieś k/Torunia, Bydgoszcz, Warszawa, Wydawnictwo Rolewski \&Wydawnictwo Uczelniane WSG \& Wydawnictwo IFiS PAN, 2009, p. 221.

${ }^{109}$ Ibidem; see also A. Chmielewski, „Racjonalizm i antyracjonalizm”, in J. Miklaszewska (ed.), Rozum a porządek społeczny, Instytut Filozofii — Uniwersytet Jagielloński, Kraków, 2002, p. 43.
} 


\section{Is the Contractarianism of Narveson Libertarianism?}

Besides such objections, authors of the festschrift of Narveson distance themselves from the thesis of the Canadian philosopher that contractarianism leads to a libertarian system. ${ }^{110}$ However, it needs to be noted that the very approach to the contractarian-libertarian relation, which has been adopted by Narveson and some of his commentators, is dubious. Since the thing is not whether contractarianism leads or can lead to libertarianism, but whether a variant of a social contract proposed by Narveson is libertarianism.

Libertarianism is a holistic strand in political philosophy. It is not a set of ideas "starting" at the moment of choosing a political system. Rather libertarianism is a complete structure built upon the cornerstones of ontology, epistemology, anthropology and ethics. Libertarian philosophy assumes a particular ontological status of the world and of a man. Ontological (combined with epistemological) ideas of human being lead to an axiological ideas of their status. This is a background of libertarianism which a libertarian philosopher possesses when he starts his ethical/political reasoning. Namely, the background is an idea of an individual as a subject of rights. ${ }^{111}$ Hence, we should not ask if Narveson's contractarianism leads to libertarianism, but if his variant of contractarianism is consistent with libertarianism.

One of the main ideas of libertarianism is voluntariness. ${ }^{112}$ Appealing to this category could serve as an another argument for regarding Narveson's ideas as libertarian. Within his social contract tradition a voluntariness of contracting parties, even if hypothetical, is crucial - to arise or explain social morality, duties (even if only negative ones) towards others, to create law, society and the state. However, when libertarians appeal to voluntariness, they already accept the particular starting point regarding anthropology and ethics. Thus they assume the right to self-ownership and the non-aggression principle. As a result, strictly normative attributes and rights derived from them comprise an ontological structure of human being and this structure is not dependent on relations or contracts they reach.

\footnotetext{
${ }^{110}$ See S. Dimock, "The Value of Values: The Importance of Autonomy in Contractarian Reasoning", in M. Murray (ed.), op. cit.; M. Murray, "Why Contractarians Are Not Libertarians... Evolutionarily Speaking", in ibidem; L. Groarke, op. cit.

${ }^{111}$ See R. Nozick, Anarchy, State, and Utopia, Oxford, Basic Books, 1974; M. N. Rothbard, The Ethics of..., op. cit.; H.-H. Hoppe, The Economics and Ethics of Private Property. Studies in Political Economy and Philosophy, 2nd Edition, Auburn, Alabama, Ludwig von Mises Institute, 2006; idem, A Theory of Socialism and Capitalism. Economics, Politics and Ethics, Auburn, Alabama, Ludwig von Mises Institute, 2010.

${ }^{112}$ See W. Block, "Libertarian Perspective on Political Economy", in H. Bouillon (ed.), Libertarians and liberalism. Essays in Honour of Gerard Radnitzky, Avebury, Aldershot, 1996, p. 19; D. Boaz, Libertarianism: A Primer, New York, The Free Press, 1998, p. 15; Ch. Kukathas, "Two Constructions of Libertarianism”, in Libertarian Papers 1, 11, 2009, p. 12.
} 
Narveson's approach is different: "My argument, then, does not presuppose the libertarian scheme of rights. Instead it argues for those rights, by showing that the scheme of rights can be expected to work out better for every reasonable person, if applied uniformly to all, than any alternative scheme". Moreover, as he forcily ${ }^{113}$ claims: "Morality in general, and liberty in particular, are to be defended here as means, not as ends". 114 A source of ethical obligation in Narveson's philosophy is neither anthropology nor - in a broader sense - ontology, nor epistemology, but only a contract. In his opinion, none of the disciplines mentioned above have normative or magnitudegenic implications. His reflections are dominated by meta-ethics ${ }^{115}$, whereas a hallmark of libertarianism is an anthropological reflection preceding and determining ethical views; see also Machan's critique above).

Thus, the author of The Libertarian Idea sees voluntariness in a different way than libertarians do. Libertarianism does not make the rights of a man to his or her body and private property conditional on a voluntary agreement, but it recognizes them as objective on philosophical (ontological etc.) grounds. If we assume that a particular individual is unusually reluctant to interpersonal relations, so he lives a life without reaching any agreements with others, indeed without speaking to them, that does not indicate he has lost or never had any rights.

As described above, in the approach of Narveson even establishing property rights requires a previous "prior agreement" (or "a pre-market bargaining") in order to make reaching a proper social contract possible (of course, not in a concrete act of contracting). Hence, "the Libertarian Principle" concerns exclusively those people who accepted that agreement. The rest can be drowned in the tar-pit - as Narveson claims, although he certainly wishes that all members of the community agreed to the two voluntary social contracts.

But is it still voluntary? What about the disabled, handicapped people, and small children who cannot rationally deliberate and who are unable to ponder the political order or articulate their standpoint? Furthermore, following Narveson's line of thought, one needs to conclude that reaching a social contract with such people is often unprofitable, since they often are not dangerous in a Hobbesian sense: "as to strength of body, the weakest hath enough to kill the strongest". ${ }^{116}$ They often cannot even ask (or hire) anybody to harm somebody. Those, who for some reason cannot take part in negotiations (even "tacit" ones), are at the mercy of the rest-in the brutal Hobbesian world it is not obvious they must survive. Which libertarian would agree? It is worth remembering the critique by Machan who demands rights of every

\footnotetext{
${ }^{113}$ J. Narveson, Contracting for Liberty, op. cit., p. 38.

${ }^{114}$ Idem, The Libertarian Idea, op. cit., p. 168.

${ }^{115}$ A wide approach to meta-ethics as defined by F. Ricken, Etyka ogólna, transl. P. Domański, Kęty, Antyk Marek Derewiecki, 2001.

${ }^{116}$ As quoted in J. Narveson, Contracting for Liberty, op. cit., p. 22.
} 
person from a strict libertarian point of view-that individual rights are objectively knowable notwithstanding the agreement.

Thus, we cannot stress enough that, in opposition to libertarianism, Narveson regards all ethical issues as conventional, indeed in the most radical sense of a term. For a convention does not mean here a culture, a tradition, or an ethos. It is not considered as "a wisdom of ancestors," but it can be created ad hoc. It is then a rationalistic conventionalism - a child of the left, and not a child of conservatism and traditionalism. ${ }^{117}$ Moreover, Narveson's thought is a sort of constructivism, albeit in a conventionalist variant, where the subject of a tacit political "construction" is demos. It seems that a non-conventional part of his philosophy consists only of some assumptions of a subject (as, for example, pursuing one's own interest). It is worth mentioning that in the opinion of Justyna Miklaszewska ${ }^{118}$ this is natural rights libertarianism, and not market contractarianism, that is a sort of constructivism (in the Hayekian sense of "false individualism"). Nevertheless, she seems to mean a constructivism conceived by a theoretician's blueprint of an ethical system. Anyway, in strict libertarianism, ethics is derived from an objective philosophical point of view ${ }^{119}$ and not from a close cousin of relativism - a constructivist conventionalism, as in Narveson's views. Admittedly, in a political sense, libertarianism is identified by its voluntary character, yet there is no doubt that libertarian philosophy recognizes an objective character of the assumptions regarding rights of individuals.

We can say that the idea of voluntariness is distorted in the thought of the Canadian philosopher. It seems so because of an idea of reciprocity which he proposes and which is not libertarian in nature - at least not in so extreme sense. Narveson argues in Hobbesian fashion: "[Contractarianism] holds that the principles of morals, whatever they may turn out to be, are those we all do have reason to agree on provided all others accept them as well. (...) [A]bsent agreement, we revert to the unsatisfactory condition in which no one can trust anyone else. Libertarianism is a view about the substance of that agreement". ${ }^{120}$ This quotation makes a point that there cannot be a portion of society outside the agreement. We can see merely an all or nothing approach. Hence, we either have morals and laissez-faire politics or a chaotic state of nature. However, this view seems unrepresentative of Narveson, since- as was mentioned above - he considers a situation where not everybody would like to accede to the social contract. We can incline towards a hypothesis that in that case he draws too much inspiration from Hobbes. Not in a normative, but in a theoretical sense, for

\footnotetext{
${ }^{117}$ Cf. J. Bartyzel, Śmiertelny bóg Demos, Fijorr Publishing, Warszawa, 2009, Lecture III; A. Chmielewski, "Filozoficzna idea liberalizmu", in J. Miklaszewska (ed.) Liberalizm u schytku XX wieku, Kraków, Meritum, 1999, p. 248.

${ }_{118}$ J. Miklaszewska, Libertariańskie koncepcje wolności i własności, Kraków, UJ, 1994, p. 18.

${ }^{119}$ See M. N. Rothbard, The Ethics of ..., op. cit.; H.-H. Hoppe, The Economics and Ethics..., op. cit.; idem, A Theory of Socialism..., op. cit.; R. Nozick, op. cit.

${ }^{120}$ J. Narveson, Contracting for Liberty, op. cit., p. 25.
} 
the view of Hobbes quoted above is ultimately inconsistent with Narveson's own view.

He claims: "Participants in bargaining games can settle wherever they please-so says the Lockean Proviso (aka libertarian principle). Once settled, society can insist that they keep the agreement made, but society simply has nothing to say about how they should settle, short of avoiding force and fraud in the negotiation" 121 and adds: "Non-violence and cooperation are »sine qua nons « of the social game". ${ }^{122}$ Surprisingly, these quotations manifest the strictly libertarian character of Narveson's philosophy. Those are the ideas propagated by all representatives of libertarianism. However, when we interpret his thought entirely, we should remember that in his opinion: "[O]ur fundamental conception must be Hobbesian: we start with no morals at all". ${ }^{123}$ Therefore, there is a need of "a prior agreement." While this "libertarian principle" dictates a respect for private property, it is not accepted as absolute and objective, but it is itself a subject of a social contract. Questions about whether the approach of Narveson is indeed libertarian become more and more serious.

It is worth to ask why Narveson appeals, albeit often only implicitly, to two social contracts. The problem is not completely clear, but one can propose some interpretation. For it seems "a prior agreement" serves to establish (social) morality, whereas the second sort of a contract is aimed at adopting a principle which regulates social relations, i.e. a political system. So the latter concerns politics. Thus, in this respect Narveson is an atypical continuator of Hobbes. For in the philosophy of an English thinker, state and society, morals and politics, appear at the same time as a consequence of one social contract. Again, Narveson's ideas are more similar to Pufendorf who distinguishes two social contacts and one decree to thus justify an institution of the state. Thus, social morality and politics are not synonyms in the philosophy of Narveson.

The question about purposefulness of the division into two contracts maintains relevant. It seems the aim is to adopt "the Libertarian Principle" on a moral level in order to then legitimize it on the political one - of course this may not occur, but Narveson encourages people to do it. Hence, the aim would be a peculiar legitimization of a political institution. The extremely important thing is that, according to the Canadian thinker, libertarianism is a system emerging in the second contract. ${ }^{124}$ It is a proof that the views of Narveson are not libertarian, at least as it is characterized in this chapter. His views can be labelled simply as laissez-faire.

Additionally, it can be useful to carry out a thought experiment. Let us ask: could Narveson recognize a proposal of libertarians who are, according to his terminology,

\footnotetext{
${ }^{121}$ Idem, Social Contract..., op. cit, p. 229.

122 Ibidem, p. 239.

${ }^{123}$ Ibidem, p. 229.

${ }^{124}$ See idem, Why Liberty?, op. cit., p. 299.
} 
intuitionists? Such a question seems to be rather trivial, but in fact is interesting and enables a deeper argument as regards the relation of Narveson's thought and libertarianism. To answer the above question we need to consider his seemingly obvious standpoint on views of typical libertarians. Let us consider the views of Rothbard ${ }^{125}$ and Hans-Hermann Hoppe; ${ }^{126}$ both of them claim that they propose philosophical foundations of libertarian ethics which meet the condition of rationalist philosophizing, that is, they are intersubjectively communicative. Both claim that a tool of their work is reason. Not just reason, but human reason, which man as a species possesses. Thus they claim that the views they advocate are not just their views, but the necessary judgements, that cannot be rationally rejected. Of course, we should notice that this description applies to Hoppe to a much greater extent. Narveson rejects such approaches to moral philosophy and defines them as theories based on intuition. He rejects them, because he is much more liberal than Rothbard or Hoppe. Liberal in a philosophical sense of the term, we should add, but of course it has also consequences for his political views. We can suppose that the theories of Rothbard and Hoppe would be characterized by him as (too) transcendent or metaphysical, whereas he seems to prefer a liberal prescinding from metaphysics.

Since people can have different views of human nature, evidenced by the existence of people adhering to different ethical systems, there is no universal natural rights or intuitionist means for justifying a political system. Such beliefs induce him to recognize the social contract theory as justified. ${ }^{127}$

After these considerations have been presented, we can finally answer the abovementioned question: could Narveson recognize a proposal of libertarians who are, according to his terminology, intuitionists? The answer is: "yes" and "we do not know", and the choice depends on who we ask-Narveson-political-philosopher or Narveson-moral-subject.

Of course, as a political philosopher he explicitly rejects proposals of theorists whom he regards as intuitionists. But it is difficult to know what is his personal "intuition" (and whether he has one)—what is an opinion of his as the moral subject. It is clear that he must believe that his own intuition is as subjective as the intuitions of others. That is why he would not mention in his philosophical writing on morality and politics his individual, subjective or intuitive opinion on human nature (if he had one), since he considers it as invalid in those branches of philosophy. For he regards it as a subject of a metaphysical speculation which everybody is allowed to undertake, but which is unknowable within rational cognition of normative principles of ethics and politics. Thus, according to him, it is an approach that does not meet the criteria of intersubjective verification. Nevertheless one cannot rule out that Narve-

\footnotetext{
${ }^{125}$ See M. N. Rothbard, The Ethics of..., op. cit.; idem, For a New Liberty, op. cit.

${ }^{126}$ See H.-H. Hoppe, The Economics and Ethics..., op. cit.; idem, A Theory of Socialism..., op. cit.

${ }^{127}$ J. Narveson, Why Liberty?, op. cit., pp. 298-299.
} 
son-moral subject accepts the approach of Rothbard or Hoppe, but it would be-let us repeat - irrelevant for him as the political philosopher. Anyway, the crucial thing is that Narveson does not mention that natural rights do not exist. He merely points out that people can have different opinions on that matter, so appealing to the idea of natural rights is not functional. However, if he had such an opinion as the moral subject, he would be in a closer position to libertarians from whom he would then differ epistemologically and ontologically.

But how can one know that if Narveson, as the moral subject, adopts some natural rights theory, it is consistent with the libertarian standpoint? One can know because his contractarianism is market contractarianism beginning with bargaining individuals aware of their self-interests capable of reaching a social contract with an imperative of obeying it. Finally, one can know, since the political system he proposes to establish by a contractarian method - designed as a compromise - could not contradict his own idea of natural rights (assuming he has one). For this method is meant to attract everyone - even those with ethical intuitions. On this basis one can know that respective and diverse ethical intuitions must square with the contractarian "Liberty Principle" postulated by Narveson. Thus, the requirement must apply also to his own intuitions.

So it is possible that personally the philosopher is inclined towards a libertarian "intuitionism", ${ }^{28}$ but uses contractarianism as an instrument which meets his philosophical criteria. If this is the case, it would be nothing new. For it would be a similar strategy to that which is used by Christian authors who try to prove religious truths by appealing to rationalist doctrine of natural law (but which, one should admit, is consistent with Christianity on a basis that there is natural moral law written into a conscience of human beings).

However, in the light of the foundations of libertarianism, as they are presented in this chapter, even such assumption could not make the contractarian proposal of Narveson libertarianism sensu stricto. Although he is a careful commentator of libertarian political philosophy, there are too many differences between his philosophical approach and the tradition of thinking which is represented by libertarians. Hence, his philosophical assumptions and their practical implications are inconsistent with libertarianism.

\footnotetext{
${ }^{128}$ It should be noted that it is not an interpretation of the philosophy of Narveson, but an assumption for the sake of recognizing a thesis.
} 